\title{
The burgeoning field of transdisciplinary adaptation research in Quebec (1998-): a climate change-related public health narrative
}

This article was published in the following Dove Press journal:

Journal of Multidisciplinary Healthcare

14 September 2011

Number of times this article has been viewed

\author{
Pierre Gosselin ${ }^{1-3}$ \\ Diane Bélanger ${ }^{1,3,4}$ \\ Véronique Lapaige ${ }^{1,5,6}$ \\ Yolaine Labbé \\ 'Quebec National Public Health \\ Institute, Quebec, ${ }^{2}$ Laval University, \\ Faculty of Medicine, Department \\ of Social and Preventive Medicine, \\ Quebec, ${ }^{3}$ National Institute of \\ Scientific Research, Water-Earth- \\ Environment Centre, Quebec, \\ ${ }^{4}$ Research Centre of the Quebec \\ University Hospital Centre, Quebec, \\ ${ }^{5}$ University of Montreal, Faculty of \\ Medicine, Department of Psychiatry, \\ Montreal, ${ }^{6}$ Fernand-Seguin Research \\ Centre, Montreal, QC, Canada
}

Correspondence: Pierre Gosselin Institut national de santé publique du Québec, Direction de la santé environnementale et de la toxicologie, Unité Santé et Environnement - Eau, Air et Climat, 945 rue Wolfe, Quebec (QC) GIV 5B3, Canada

Tel +I 4I8650 5I I5

Fax + I 4186543144

Email pierre.gosselin@inspq.qc.ca
Abstract: This paper presents a public health narrative on Quebec's new climatic conditions and human health, and describes the transdisciplinary nature of the climate change adaptation research currently being adopted in Quebec, characterized by the three phases of problem identification, problem investigation, and problem transformation. A transdisciplinary approach is essential for dealing with complex ill-defined problems concerning human-environment interactions (for example, climate change), for allowing joint research, collective leadership, complex collaborations, and significant exchanges among scientists, decision makers, and knowledge users. Such an approach is widely supported in theory but has proved to be extremely difficult to implement in practice, and those who attempt it have met with heavy resistance, succeeding when they find the occasional opportunity within institutional or social contexts. In this paper we narrate the ongoing struggle involved in tackling the negative effects of climate change in multi-actor contexts at local and regional levels, a struggle that began in a quiet way in 1998. The paper will describe how public health adaptation research is supporting transdisciplinary action and implementation while also preparing for the future, and how this interaction to tackle a life-world problem (adaptation of the Quebec public health sector to climate change) in multi-actors contexts has progressively been established during the last 13 years. The first of the two sections introduces the social context of a Quebec undergoing climate changes. Current climatic conditions and expected changes will be described, and attendant health risks for the Quebec population. The second section addresses the scientific, institutional and normative dimensions of the problem. It corresponds to a "public health narrative" presented in three phases: (1) problem identification (1998-2002) beginning in northern Quebec; (2) problem investigation (2002-2006) in which the issues are successively explored, understood, and conceptualized for all of Quebec, and (3) problem transformation (2006-2009), which discusses major interactions among the stakeholders and the presentation of an Action Plan by a central actor, the Quebec government, in alliance with other stakeholders. In conclusion, we underline the importance, in the current context, of providing for a sustained transdisciplinary adaptation to climatic change. This paper should be helpful for (1) public health professionals confronted with establishing a transdisciplinary approach to a real-world problem other than climate change, (2) professionals in other sectors (such as public safety, built environment) confronted with climate change, who wish to implement transdisciplinary adaptive interventions and/or research, and (3) knowledge users (public and private actors; nongovernment organizations; citizens) from elsewhere in multi-contexts/environments/sectors who wish to promote complex collaborations (with us or not), collective leadership, and "transfrontier knowledge-to-action" for implementing climate change-related adaptation measures.

Keywords: climate change, impacts, adaptation, public health, Quebec, Canada, Arctic, intersectoral approach, complex collaborations, collective leadership, transfrontier knowledge-to-action, narrative, storytelling, success story 


\section{Introduction}

There is abundant evidence that human activities are altering the earth's climate ${ }^{1,2}$ and that climate change endangers human health, ${ }^{3}$ affecting all sectors of society both domestically $^{3-8}$ and globally. ${ }^{3,9,10}$ Natural processes have always influenced global change but anthropogenic activities - in particular the burning of fossil fuels and changes in land-use patterns - are considered to be the main reasons for the changing climatic conditions observed since the mid-20th century. ${ }^{3}$ In this paper the term "climate change" refers to any change in climate over time, whether a product of natural factors, human activity, or both. This usage is the same as that of the Intergovernmental Panel on Climate change, ${ }^{1,3}$ but it differs from the usage in the United Nations Framework Convention on Climate Change, ${ }^{2}$ which restricts the term to climate changes that can be directly or indirectly related to human activity and are additional to natural climate variability.

The environmental repercussions of climate change, both those already observed and those expected - including an unprecedented rate of warming, widespread retreat of glaciers, rising sea levels, changes in the frequency and severity of extreme weather events (eg, floods, droughts, heat waves, severe storms) - will affect human health both directly and indirectly. ${ }^{10-20}$ In 2010, the human health consequences of climate change were identified and classed into eleven broad categories covering diverse categories of medical practice by the Interagency Working Group on Climate Change and Health. ${ }^{11}$ The Fourth Assessment Report of the Intergovernmental Panel on Climate Change also outlines a wide range of anticipated consequences of economic, physical, and social environments in every region of the world. ${ }^{3,20,32,33}$ Quebec (in Canada) is no exception. ${ }^{4,6,34,44}$

Although aggressive mitigation measures - ie, anthropogenic interventions to reduce the sources or enhance the sinks of greenhouse gases - can significantly blunt the worst of anticipated exposures, some degree of climate change is unavoidable and we must adapt to its associated adverse health effects. ${ }^{5,6,12,21-31,45-59}$ Adaptation - which refers to the adjustment in natural and human systems in response to actual or expected effects of climate change and variability, and which moderates harm or exploits beneficial opportunities - is a necessary complement to mitigation in addressing climate change. ${ }^{45,46,59}$ However, adaptation interventions and research must be fundamentally transdisciplinary because of:

- multiple effects of climate change on human health (direct, indirect, cascading, and synergic) impacting through associated factors such as population vulnerabilities and the adaptive capacities of the implicated natural and human systems;

- the multiplicity of adaptation measures and the interconnectedness between these adaptation options;

- the diversity of the actors involved in adaptation research/ interventions and their varying roles and responsibilities, the "complex collaborations" and the collective leadership that must be foreseen; ${ }^{60-63}$

- the various groups of population or different types of communities (eg, isolated, resource dependent, coastal, rural and urban communities);

- the various sectors related to public health that must be taken into account (eg, public safety sector, built environment sector, water resources sector, forestry sector, agriculture and fisheries sector).

The transdisciplinary approach demands time and energy, as it requires many actors to establish themselves in a milieu historically dominated by disciplinary silos and therefore not amenable to transdisciplinary methodologies. ${ }^{64-67}$

The purpose of this paper is to present a public health narrative on Quebec's new climatic conditions and human health. But what exactly is a narrative ${ }^{68} \mathrm{~A}$ narrative can be a written, spoken, filmed, or drawn account; it can be verse or prose; it can be used to represent fictional or real events. ${ }^{68-70}$ There are four perspectives in which we can view narratives in the health sector. First, there are organizational stories whose main purpose is to create and strengthen social capital, and to contribute to the success of the organization knowledge management initiative. ${ }^{72}$ Second, there are illness narratives - people describing their subjective experience of illness - which are recognized as a major literary genre. ${ }^{71,73}$ Third, there are stories which are told by physicians practicing medicine with narrative competence. ${ }^{74,75}$ Fourth, there are public health narratives. ${ }^{76}$ The term "narrative" is used interchangeably with the term "story," although Frank has noted that it is more natural to say "let me tell you a story" than "let me tell you a narrative." "7

This public health narrative will describe the transdisciplinary nature of the climate change adaptation research currently being adopted in Quebec, characterized by the three phases of problem identification, problem investigation, and problem transformation.

Transdisciplinarity is increasingly apparent in many health organizations, institutions, research centres, and/or universities internationally. A transdisciplinary approach is essential for dealing with complex, ill-defined problems concerning human-environment interactions (for example, adaptation of the public health sector to climate change-related adverse effects), to allow joint research and significant exchanges 
among scientists, decision makers, and knowledge users. ${ }^{65}$ But although transdisciplinarity is widely supported in theory, it has proved to be extremely difficult to implement in practice, and those who attempt it have met with heavy resistance, succeeding when they find the occasional opportunity within institutional or social contexts. ${ }^{65-67}$ In this paper we narrate the ongoing struggle involved in tackling climate change negative impacts in multi-actor contexts at the local and regional levels, a struggle that began in a quiet way in 1998. The paper will describe how public health adaptation research is supporting transdisciplinary action and implementation while also preparing for the future, and how this interaction to tackle a life-world ${ }^{78}$ problem (adaptation of the Quebec public health sector to climate change) in multi-actor contexts has progressively established itself over the last 13 years.

The paper is divided into two sections. The first section introduces the social context of a Quebec undergoing climate changes. Current climatic conditions and expected changes will be described, as well as the attendant health risks for Quebeckers. The second section examines the scientific, institutional, and normative dimensions of the problem. This section corresponds to a "public health narrative" presented in three phases: (1) problem identification (1998-2002) beginning in northern Quebec; (2) problem investigation (2002-2006) in which the issues are successively explored, understood and conceptualized for all of Quebec, and (3) problem transformation (2006-2009), seeing major interactions among the stakeholders and in which a major actor - the Quebec government - presented its Action Plan in alliance with other stakeholders. In conclusion, we underline the importance, in the current context, of providing for a sustained transdisciplinary adaptation to climatic change. This paper should be helpful for (1) public health professionals confronted with establishing a transdisciplinary approach to a real-world complex problem other than climate change, (2) professionals within other sectors (for example, public safety, built environment) confronted with the problems of climate change and who wish to implement transdisciplinary adaptive interventions and/or research, and (3) multi-actors (public and private actors; nongovernment organizations, partners) in multi-contexts/environments/sectors who wish to promote complex collaborations (with us or not), collective leadership, and transfrontier knowledge-to-action for implementing climate change-related adaptation measures.

\section{Quebec in a changing climate: the societal context}

Our world is sensitive to climate change in multiple ways, through both direct and indirect exposures..$^{5,6,12,21-31,47-58}$
This sensitivity varies by territory (national, regional, local, municipal, tribal), population group, natural environment, and economic structure. Likewise, people and ecosystems have different vulnerabilities and adaptive capacities, depending on the region of the world, the structure and wealth of the economy, and the interplay of individual and collective factors. ${ }^{3,5,7,9,21}$

In Quebec, climate change will have major impacts on the population, natural and created environments, and economic activities. ${ }^{4,6,34,35}$

\section{Quebec's climate and projected climatic changes}

Several climatic changes can already be observed in the province of Quebec, Canada. In recent decades, daily mean temperature in the South has increased by $0.2^{\circ} \mathrm{C}$ to $0.4^{\circ} \mathrm{C}$ per decade, the increase being greater for minimum than for maximum temperatures. ${ }^{34,35}$ This increase is also reflected in a shorter frost season, an increase in growing degree-days, and a reduction of heating degree-days. In recent decades, there has also been a significant increase in the number of days of low-intensity rain and changes in snow precipitation, which has increased in the north of Quebec and decreased in the south. ${ }^{34,35}$

In the near future, the climate will warm up throughout Quebec, more markedly in winter than in summer. ${ }^{34,35} \mathrm{By}$ 2050 , temperatures will have increased by $2.5^{\circ} \mathrm{C}$ to $3.8^{\circ} \mathrm{C}$ in the south of the province and by $4.5^{\circ} \mathrm{C}$ to $6.5^{\circ} \mathrm{C}$ in the north. Summer temperatures will increase by between $1.9^{\circ} \mathrm{C}$ and $3.0^{\circ} \mathrm{C}$ in the south and between $1.6^{\circ} \mathrm{C}$ and $2.8^{\circ} \mathrm{C}$ in the north. Increases in winter precipitation (by $16.8 \%$ to $29.4 \%$ in the north and $8.6 \%$ to $18.1 \%$ in the south) are expected by the time horizon of 2050 , leading to an increase in snow accumulation in the north. ${ }^{34,35}$

\section{Climate risks to Quebeckers' health, now and in the future}

Impacts of climate change on many physical and biological systems in Canada (including glacier and snow cover, river-ice cover, plant phenology and productivity, animal species distribution, coastal erosion) are unequivocal and have been documented in various climate change assessments (see Table 1). . $^{3,5,7}$

As climate is a macrodeterminant of health, the relationships between climate and human health follow multiple complex pathways. ${ }^{10}$ In this paper, human health is defined as a state of complete physical, mental, and social well-being, and not merely the absence of disease or infirmity. At every stage of life, human health is influenced by complex interactions among 
Table I Effects of climate change on systems (Province of Quebec, Canada)

\begin{tabular}{ll}
\hline Affected biological and physical systems & Examples of impact \\
\hline Permafrost conditions & Most significant warming in western Arctic than in other Canadian regions \\
At least I ${ }^{\circ} \mathrm{C}$ increase in surface permafrost temperature since 1990 in northern Quebec \\
$10 \%$ decrease in extent of Northern Hemisphere $1972-2003$
\end{tabular}

the different determinants of health, including: income and social status, social support networks, education and literacy, employment/working conditions, social environments, physical environments, personal health practices and coping skills, healthy child development, biology and genetic endowment, health services, gender and culture. For example, northern communities face specific challenges in the context of climate change and variability, which influence the distribution, availability and accessibility of wildlife that contributes to their diet. ${ }^{5}$ Many determinants of health (eg, a lack of nutritious food sources, existing health disparities, the limited access to public health emergency management services, inadequate infrastructure and poor housing conditions) combine with climate and climate change to increase vulnerability. ${ }^{5}$

In Quebec, climate change has had and will have numerous effects on population health, ${ }^{4,6,36-43}$ ranging from direct effects of average warming and urban heat islands (air pollution, forest fires and wildfires, summer and winter storms, and ultraviolet ray exposure) to the indirect effects resulting from changes in the quality and quantity of water resources or in zoonotic diseases (see Table 2). In particular, higher temperatures associated with higher humidity and more frequent and intense heat waves represent significant threats to human health. Other serious problems are related to the effect of higher temperatures on air pollution, especially in the form of pollens, ozone and air-borne particulates. ${ }^{4}$

\section{Quebec public health's adaptation to climate change: the scientific, institutional, and normative context}

The public health community has been rather slow in becoming actively involved in the process set up in 1988 by the United Nations to monitor climate change. While the Europeans, through World Health Organization-Europe, began research at the end of $1999,{ }^{79}$ the remainder of the planet remained relatively quiet on the subject, except for several pioneering scientists. ${ }^{80}$

Canada and Quebec began their research in this field at a low level on the occasion of the first Adaptation Assessment of Canadian Climate Change Impacts in 1995-1996. ${ }^{81}$ Except for a few simulations of the possible reappearance of malaria in 2080 in the Toronto region, the health aspect of this Canadian assessment was theoretical in nature, without data analysis or collection, and restricted itself to a review of possible impacts by a few experts. ${ }^{81}$ The same was true for the Quebec component of the assessment, which simply came to a conclusion about the necessity of initiating multidisciplinary studies in Quebec to quantify the direct repercussions of episodes of extreme heat, floods, intense cold waves, and winter storms on morbidity, human mortality, and on the social behavior of the population in an urban or semi-urban environment. ${ }^{81}$ No feeling of urgency was reflected in the recommendations at that time (1996), and several years passed before funding began. But funding did begin, slowly at first but by now reaching full speed.

\section{Phase one or problem identification (1998-2002): documenting public health issues in the far north}

In 1998, as the result of an initial federal support program for research on adaptations to the changing climate (the Climate Change Action Fund, or CCAF, abolished in 2005), a health project began in Arctic Quebec and in Labrador, due to the more severe climate change predicted for this region, where the average warming expected is in the order of $2^{\circ} \mathrm{C}$ to $4^{\circ} \mathrm{C}$ by 2050 , with an increase of $4^{\circ} \mathrm{C}$ to $7^{\circ} \mathrm{C}$ by the end of the century for the Arctic region. ${ }^{82,83}$ The results of this first step were of interest, ${ }^{84}$ confirming the perception by the Inuit population of recent warming, and proposing a typology for the health impacts in an Arctic environment as 
Table 2 Examples of climate change-related risks for human health (potential human health impacts)

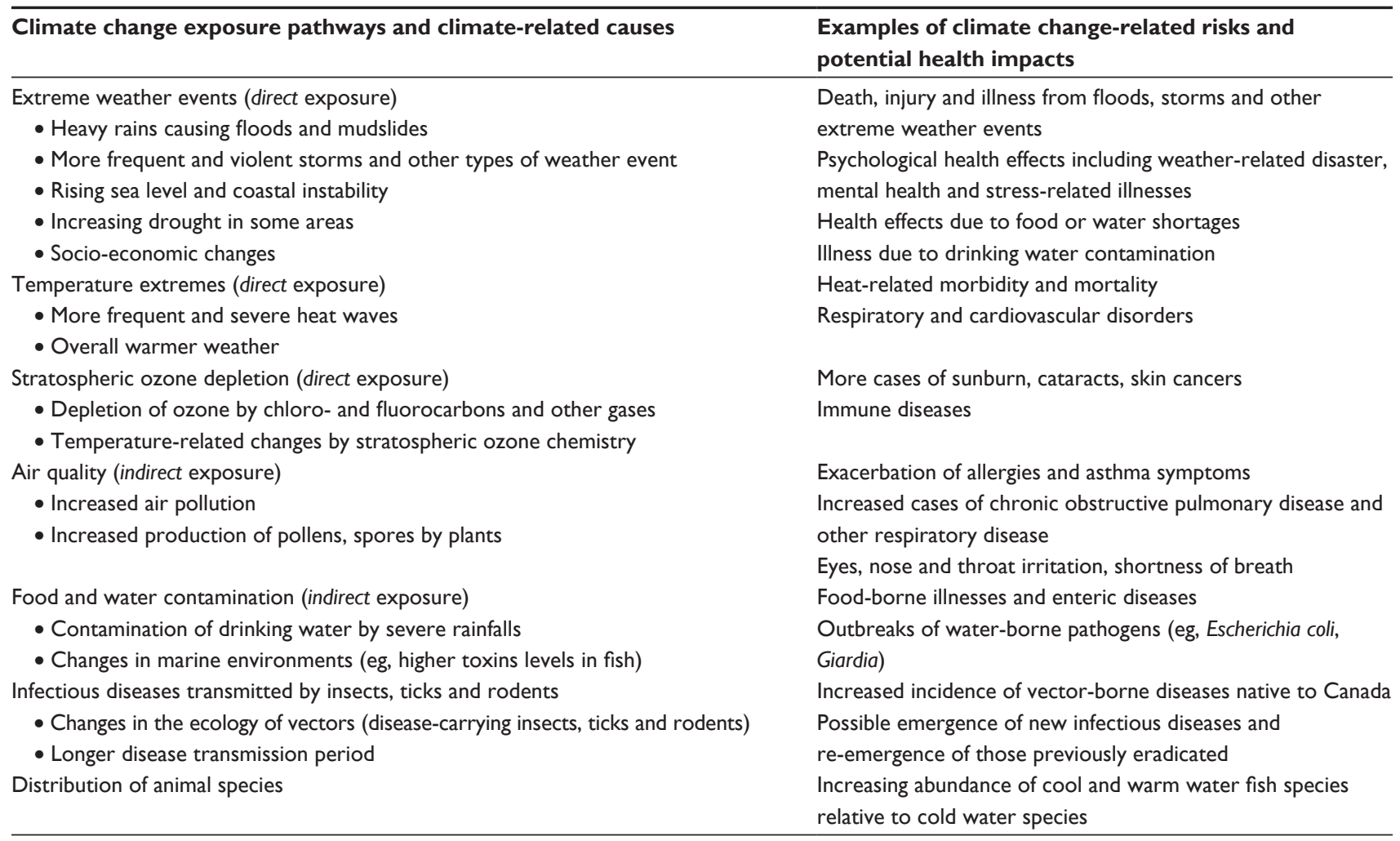

well as various intervention scenarios for adaptation. This initial process laid the foundations for a broadening of this northern research component within the consortium of the Centres of Excellence of Canada, Arcticnet, ${ }^{85,86}$ with projects involving the surveillance and measurement of health status, ${ }^{87-89}$ zoonotic diseases, ${ }^{90}$ and drinking water quality. ${ }^{91}$ The conclusions showed that if animals were affected due to climate by diseases, parasites, more biting insects, famine, or change or loss of habitat, the Inuit people would be exposed to a double change because their sources of nutrition could be transformed or displaced, thereby negatively affecting their diet. Under these conditions, their intake of highly nutritious animal protein would be reduced, a situation of some concern considering their rapid demographic growth and the noted reduction in their hunting and fishing skills. This evolution was of concern to public health officials because the replacement of traditional foods with imported foods, higher in sugar and carbohydrates would have the effect of causing cardiovascular problems, diabetes, vitamin deficiencies, anemia, dental problems and obesity, as well as lower resistance to infections in northern Quebec. Inuit people already had much higher mortality and morbidity rates than elsewhere in Quebec, mostly related to diet and smoking, ${ }^{92}$ and a reduced life expectancy, due in large part to death by injury, cancer and, to a lesser extent (because it was a young population), to cardiovascular diseases. The direct and indirect impacts of climate conditions on the natural and created environments could also increase the risks to health, safety, and the wellbeing of these isolated populations (see Table 3).

For example, the significant increase in the amount and intensity of precipitation could cause even more landslides or avalanches. Furthermore, after the nine deaths and 25 injuries resulting from the Kangiqsualujjuaq avalanche in 1999, a thorough risk assessment was done in all the villages, and many essential infrastructures (such as diesel power plants and fuel tanks) were moved preventively.

\section{Phase two, problem identification phase (2002-2006): documenting public health issues for all of Quebec}

In 2000, Quebec was recovering from two extreme weather events of rare magnitude, suffered in quick succession. The relentless rain in the Saguenay region in 1996 had subjected the region to $275 \mathrm{~mm}$ of rain in $48-72$ hours, producing floods that carried away several villages and major sections of towns, causing 10 deaths, with everything broadcast live on the first continuous news channel that had been on the air for only a few months. The scale of the evacuations and the quasi-failures of dams that could have produced cascading technological catastrophes (eg, floods and explosions of tanks of molten 
Table 3 Examples of climate change-related risks for human health (potential human health impacts) in the northern communities

\begin{tabular}{|c|c|}
\hline $\begin{array}{l}\text { Climate change exposure pathways and climate-related } \\
\text { causes }\end{array}$ & $\begin{array}{l}\text { Examples of climate change-related risks and potential } \\
\text { health impacts }\end{array}$ \\
\hline Extreme precipitation events and natural hazards (direct exposure) & Increased risk of landslide and avalanche-related mortality and morbidity \\
\hline Temperature-related injuries (direct exposure) & Respiratory impacts and other heat-related risks \\
\hline \multirow[t]{2}{*}{ Changing ice and snow conditions (direct exposure) } & Increased frequency of accidents while on ice \\
\hline & Decreased access to country food items \\
\hline Unpredictability of weather conditions (direct exposure) & $\begin{array}{l}\text { Increased frequency and severity of accidents and increased morbidity/ } \\
\text { mortality while hunting/traveling }\end{array}$ \\
\hline $\begin{array}{l}\text { Changes in air quality by contaminants, pollens and spores } \\
\text { (indirect exposure) }\end{array}$ & Increased incidence of respiratory and cardiovascular diseases \\
\hline \multirow[t]{2}{*}{ Food and water security (indirect exposure) } & $\begin{array}{l}\text { Decreased access to traditional food items and erosion of value associated } \\
\text { with the consumption of traditional food items }\end{array}$ \\
\hline & $\begin{array}{l}\text { Reduced access to potable water and increased incidence of enteric and other } \\
\text { infectious diseases }\end{array}$ \\
\hline Increased exposure to ultraviolet radiation (indirect exposure) & Increased incidence of rashes and snow blindness \\
\hline Permafrost instability; sea level rise and coastal erosion & Negative effects on public health, housing and transportation infrastructures \\
\hline (indirect exposure) & Psychological effects of infrastructure damage and community relocation \\
\hline
\end{tabular}

aluminum) also alarmed the governments, who responded with a final bill of approximately CAD $\$ 1.7$ billion.${ }^{93}$ Some 18 months later there was freezing rain of exceptional magnitude (up to $100 \mathrm{~mm}$ between January 4 and 10, 1998, or 2.5 times the previous records) which affected the entire American Northeast and some 5 million people, with a major impact in the Monteregie region, just south of Montreal. Millions of households were deprived of electricity, many for more than one month. Since residential heating in Quebec is mainly electrical and the average temperature in January is around $-10^{\circ} \mathrm{C}$, approximately 100,000 people had to be evacuated for a few days to several weeks, depending on the duration of the power failure. This ice storm was also more deadly, with some 28 fatalities and numerous hospitalizations, and is considered as the most costly in Canadian history, with total compensation exceeding CAD $\$ 3$ billion and additional electrical network reconstruction costs of some CAD $\$ 2$ billion. ${ }^{94,95}$

In response to these catastrophes, the Montreal-based Ouranos Consortium ${ }^{34}$ - Consortium on Regional Climatology and Adaptation to Climate Change - was created in 2001-2002 due to the great political and social awareness of the impacts of extreme weather events, the need to have a clearer view about climate change, and to prepare for the future. From a health perspective, however, the Quebec (provincial) ministry of health remained rather unconvinced about the importance of becoming an active member of this new consortium, in spite of its being supported by 10 government departments and four universities, preferring instead to address other, better documented, priorities. The European and mainly French heat wave in the summer of 2003 changed this situation. Shortly afterwards, the Quebec ministry of health decided to join Ouranos by devoting additional human and financial resources, with the financial support of Health Canada and the Canadian Institutes of Health Research. ${ }^{34}$

Numerous scientific projects resulted from this initial program (see Table 4), which addressed mainly the effects of average warming on historic and future mortality, and the perceptions and attitudes of the population and public institution managers regarding the effects of climate change on health and how to counter them. Studies were also conducted on airborne allergens, some vector-borne diseases, and on the current status of various measures recommended by international bodies as useful to health adaptation. ${ }^{36-43}$ The results were extremely interesting, leading to publications and reports, and permitting the development of important links with teams from other government departments and universities. ${ }^{36-43,96-102}$ For the first time, these publications characterized the extent of the impacts of average warming on future mortality in Quebec, thus allowing this phenomenon to be placed in the same quantitative context as road injuries in terms of expected future impacts.

Average warming in southern Quebec will likely have major negative impacts on health, and will probably be large in scope, as indicated by the simulations carried out on future mortality. ${ }^{35}$ Despite a reduction in winter mortality related to warming, excess summer mortality dominates the profile. In absolute numbers of deaths (and in percentages), the increased burden would be in the order of 150 annual deaths $(0.5 \%)$ around the year 2020, 550 annual deaths (1.5\%) around 2050, and 1400 (3.5\%) around 2080 for southern Quebec (total population of 8 million). This is probably a low estimate of the expected impacts, because these simulations do not take into account the fact that the population of Quebec will age greatly during this 
Table 4 Three-year research projects adapted by the Ouranos Consortium in Quebec (2006-2009)

\begin{tabular}{|c|c|}
\hline Projects theme & Examples of projects \\
\hline Heat waves and climate warming & $\begin{array}{l}\text { Historical analyses of hospital morbidity, emergency room services evaluation, and analysis of } \\
\text { mortality as a function of historic temperatures and simulated analyses, for 2020, } 2050 \text { and } 2080 . \\
\text { Implementation of roundtables to assess the measures required for adaptation to climate change: } \\
\text { institutional and clinical components. } \\
\text { Identification of sectors vulnerable to severe heat in a Canadian/Quebecker metropolis for intervention } \\
\text { and research on public health. }\end{array}$ \\
\hline Other extreme weather events & $\begin{array}{l}\text { Feasibility study for the development of real- and non-real time tools for surveillance of the health } \\
\text { effects of extreme weather events. }\end{array}$ \\
\hline Air quality & $\begin{array}{l}\text { Estimation of future smog levels with the United Regional Air-quality Modelling System (AURAMS) } \\
\text { and the Canadian Regional Climate Model (CRCM). } \\
\text { Final spatial variations in mortality and hospitalization with extreme weather events in urban } \\
\text { environments. }\end{array}$ \\
\hline Water quality & $\begin{array}{l}\text { Feasibility study of water management projects using current Ouranos water projects. } \\
\text { Incidence and distribution of gastrointestinal illnesses among populations at risk and the risk factors } \\
\text { associated with climate and agricultural practices. }\end{array}$ \\
\hline $\begin{array}{l}\text { Integration, communication, and } \\
\text { strategic support }\end{array}$ & $\begin{array}{l}\text { Development of an interactive atlas on health vulnerabilities associated with climate change. } \\
\text { Integration and transfer of knowledge and support of the Ouranos activities by the Quebec Ministry } \\
\text { of Health and its network, Health Canada, and the World Health Organization. }\end{array}$ \\
\hline
\end{tabular}

period and that the proportion of people 65 years of age and older (who are physiologically more sensitive to fluctuating weather conditions) would more than double during this period. Neither do these simulations include the excess mortality that would result from more numerous and severe extreme weather events such as heat waves or storms, or the effects of expected increases of some water-, vector- or food-borne infectious diseases. Major deficiencies were also noted in the existing surveillance systems for zoonotic and vector-borne diseases, and in the non-existence of systems to respond to the health impacts of extreme weather events. ${ }^{35}$ However, these studies have also shown that the will of the population and its public officials to act was great, immediate, and open to many options, mainly community-related (such as public transport, more stringent standards, adaptation of the created environment for groups at risk).

The results of this research were also featured in a chapter on Quebec in the 2008 Canadian national Assessment of Vulnerabilities and Adaptive Capacity; ${ }^{4}$ in fact, only Quebec and the northern regions have as yet systematically evaluated the health impacts and needed adaptations, thanks principally to the Arcticnet network directed from Laval University for the North. The other Canadian provinces and territories are only beginning to carry out this exercise. ${ }^{5}$

\section{Phase three, problem transformation phase (2006-20I3): the increasing interaction between research and adaptation interventions}

A new research program was readily accepted by Ouranos for 2006-2009, with the same financial partners (see Table 4). ${ }^{5,34}$
The topics addressed were broadened to include hospital morbidity, interaction with present and future atmospheric pollution, water-borne gastroenteritis, knowledge transfer/ translation activities, and development of web mapping tools. ${ }^{103}$

The prioritization of adaptation projects based on more solid knowledge also became possible in the new Quebec government action plan (2006-2012 Climate Change Action Plan), which was discussed early in 2006. This action plan was prepared in the political context of the January 2006 federal election of a Conservative government opposed to real implementation of the Kyoto Protocol in Canada, and therefore to any program involving climate change. After 3 years of unsuccessful negotiations between the Canadian federal government, opposed to the actual implementation of the Kyoto Protocol, and the Quebec government regarding the funding of its Climate Change Action Plan, ${ }^{102}$ Quebec finally decided to go it alone in June 2006 and to introduce the first carbon tax in North America. Established in November 2007, it is a carbon charge that major distributors pay per volume of hydrocarbons sold based on their intensity of carbon dioxide $\left(\mathrm{CO}_{2}\right)$ production. ${ }^{104}$ This charge is therefore reflected in the final price to the consumer. This tax is completely dedicated to the Green Fund, which is used to finance the government Climate Change Action Plan. This action plan consists of a series of 26 action packages targeting mitigation as much as adaptation measures, mainly in public health and emergency preparedness. ${ }^{102}$ The tax ensures a stable revenue of approximately CAD $\$ 200$ million per year which, 
however, still remains marginal in the overall government budget (approximately $0.3 \%$ ). ${ }^{104}$

By implementing this first carbon tax in the Americas, the Quebec provincial government found a way on its own to reduce greenhouse gases while initiating climate change adaptation actions, including actions in the field of public health. ${ }^{102,104}$ The 2006-2012 Climate Change Action Plan was therefore announced in June 2006. Slightly more than a year was still needed for the carbon tax to become operational and to provide money for the Green Fund, dedicated to the Action Plan in October 2007.

The Quebec Minister of Health therefore mandated the Quebec National Public Health Institute in October 2007 to manage the health component of its Climate Change Action Plan. In the context of this mandate, the Quebec National Public Health Institute must, in a more specific way, implement the following concrete adaptations:

- To design, develop, and implement, for 2012, an integrated monitoring-warning and surveillance system, based on existing regional systems, which would operate in real time to evaluate the health impacts of heat waves, for all regions of Quebec which could be affected by this risk;

- To propose, for 2012, climate modules specific to the infectious disease surveillance systems in order to allow: (a) the timely detection of certain pathogenic agents, vectors, or targeted diseases; (b) the identification of the regions or zones at risk; (c) analysis of the distribution and outbreaks of climate-sensitive infectious diseases;

- To set up an operational surveillance system for the health impacts of major extreme weather events (EWEs) and their consequences (winter and summer storms, thunderstorms and torrential rains, tornadoes, forest fires, floods, landslides, coastal erosion) in Quebec for 2012;

- To support the development and continuous updating of guidelines and guides applicable to health care establishments in the health network for their preventive adaptation to climate change (upgrading of buildings and land for heat waves and other EWEs) and to support their progressive implementation. To propose and support the application of guidelines, criteria, and practical tools for clinical, social, and public health intervention applicable in institutions, in substitute living environments, at home and in the community, in a context of preventive adaptation to EWEs;

- To implement supporting programs for municipalities and for educational networks and schools in order to promote the reduction of urban heat islands and the preventive adaptation of programs and infrastructures to climate change;
- To set up a continuous training program on the physical/ mental health and psychosocial impacts of climate change, how to deal with them and the appropriate preventive measures for health professionals, emergency preparedness professionals and personnel from other relevant sectors (ie, the public sector). To develop and propose additions to existing university and college curricula in the training of targeted personnel. To implement knowledge transfer/translation activities for the preceding specific actions.

This major research and adaptation action plan is supplemented by a renewal of the smaller joint Ouranos-Quebec National Public Health Institute research program, with the constant financial support of the Quebec Minister of Health and Health Canada, for 2009-2014. The aim of all this research is to consolidate the knowledge base on issues addressed up to now, while initiating new avenues of transdisciplinary research, mainly in public housing, zoonotic and vector-borne diseases, atmospheric pollution and climate interactions, and the impact of extreme weather events on certain high cost injuries and diseases (such as hip fracture and strokes).

\section{Conclusion}

The different research and adaptation activities described above (phases one, two, and three) could not have taken place without a favorable financial context, strong institutional incentives for transdisciplinarity, and openness to public health innovation.

One cannot forget that numerous other (probably more) urgent problems are in the media spotlight every day. Nevertheless, it was possible to create this favorable context in Quebec. The initial budgets modestly supported research (approximately CAD\$500,000 annually). The research component then grew and is now at approximately CAD $\$ 1$ million annually. The action plan (which also includes some applied research components but mainly pilot projects, planning for health network adaptations, and development of information systems for monitoring and surveillance), forecasts a budget of approximately CAD $\$ 5$ million per year. The next step, around 2013, will likely consist of mainstreaming a climate and health component into the normal and regular cycles of governmental and private expenditures, in order to prevent climate-related impacts or reduce their effects on public health. A 2013-2020 Quebec adaptation strategy will be the formal framework for this. This strategy will be approved by government next year, and will most likely develop significant transdisciplinary adaptation activities and interministerial collaborations.

Numerous lessons can be learned from the transdisciplinary adaptation process that Quebec has undergone in the 
last 13 years. These messages are rather classical in terms of governance, but still deserve to be kept in mind. We note that the dedicated research budgets, while modest, have allowed the creation of competent teams and an accurate consideration of the multiple facets of the climate change-related impacts in the orientation of public health adaptations. The various reports produced also show that most public health adaptations do not require a great deal of innovation, but rather an involvement of different stakeholders and a strengthening of the infrastructures and management methods of health and governmental authorities. The only true innovation (and major requirement) involved the need for more interuniversity, interdepartmental and transdisciplinary work. Finally, it remains important, as elsewhere, to take advantage of windows of opportunity to promote transdisciplinary adaptation research and to consolidate public health actions. These opportunities allow the development of the disciplinary and transversal competencies (collective leadership, ${ }^{63}$ complex collaborations, ${ }^{60,61}$ transfrontier knowledge integration ${ }^{62,105,106}$ ) necessary for the inclusion of these risk prevention, community strengthening, and public health protection concerns.

In conclusion, we have presented the implementation process for the first (and still the only) integrated public health research and action program in climate change in Canada, based on a single province; only Health Canada is conducting a more modest pilot research program on extreme heat alert systems and on zoonotic and vector-borne diseases. Recent initiatives in Ontario and British Columbia suggest that this move toward transdisciplinary adaptation research and practices will soon broaden to a larger proportion of the Canadian population. Such initiatives cost government budgets very little (approximately 0.0001 of the Quebec government budget for the health programs described here), but will likely allow protection at very low cost against many risks.

The ongoing diffusion of transdisciplinary concepts, the transfer of transdisciplinary research results, and the translation of possible transdisciplinary solutions is an essential condition for the success of such proposals. Any government initiative must be supported continuously by the population, local decision makers, and community organizations. In this spirit, the coming years will see additional emphasis placed on "transfrontier" knowledge utilization and transfer/translation, knowledge popularization, and education ${ }^{105-107}$ in adaptation to climate change, and the promotion of community adaptation activities.

This public willingness to act is very far from the current themes of the supposed necessity of always innovating technologically in order to remain competitive. After all, to reduce greenhouse gas emissions, fewer of these must be produced. The technologies to do this have long existed. They are called bicycles (invented in 1817); trains (1804); streetcars (1832); taxes ( 2400 years); forestry ( $~ 8000$ years); urban planning ( $\sim 10,000$ years); boats ( $\sim 10,000$ years); and walking $(\sim 2,000,000$ years).

The same is true for public health adaptations, which must mainly target the less affluent, the socially isolated, the disabledin short, the most vulnerable - while at the same time rendering society's difficult choices easier for everyone to make. We will not reinvent the public health approach but we must implement it even more vigorously, with more transdisciplinarity.

\section{Disclosure}

The authors report no conflicts of interest in relation to this paper.

\section{References}

1. Solomon S, Qin D, Manning M, et al, editors. Climate Change 2007: The Physical Science Basis. Working Group I Contribution to The Intergovernmental Panel on Climate Change Fourth Assessment Report. Cambridge, UK: Cambridge University Press; 2007.

2. United Nations. United Nations Framework Convention on Climate Change. New York, NY: United Nations; 1992. Available from: http://unfccc.int/ resource/docs/convkp/conveng.pdf. Accessed, August 9, 2011.

3. Confalonieri U, Menne B, Akhtar R, et al. Human health. In: Parry ML, Canziani OF, Palutikof JP, van der Linden PJ, Hanson CE, editors. Climate Change 2007: Impacts, Adaptation and Vulnerability. Working Group II Contribution to the Intergovernmental Panel on Climate Change Fourth Assessment Report. Cambridge, UK: Cambridge University Press; 2007: 391-431.

4. Gosselin P, Bélanger D, Doyon B. Health impacts of climate change in Quebec. In: Séguin J, Berry P. Human Health in Changing Climate: A Canadian Assessment of Vulnerabilities and Adaptive Capacity; Synthesis Report. Ottawa: Health Canada; 2008: 211-342. Available from: http://www.ptaff.ca/blogue/wp-content/uploads/human_health_ in_a_changing_climate.pdf. Accessed July 28, 2011.

5. Séguin J, Berry P. Human Health in Changing Climate: A Canadian Assessment of Vulnerabilities and Adaptive Capacity; Synthesis Report. Ottawa: Health Canada; 2008. Available from: http://www.ptaff.ca/ blogue/wp-content/uploads/human_health_in_a_changing_climate. pdf. Accessed July 28, 2011.

6. Gosselin P. Health. In: DesJarlais C, Bourque A, Decoste R, et al, editors. Adapting to Climate Change. Montreal: Ouranos Consortium; 2004. Available from: http://www.ouranos.ca/en/publications/about-climatechange.php. Accessed July 28, 2011.

7. Lemmen DS, Warren FJ, Lacroix J, Bush E, editors. From Impacts to Adaptation: Canada in a Changing Climate 2007. Ottawa: Government of Canada; 2008. Available from: http://adaptation.nrcan.gc.ca/ assess/2007/index_e.php. Accessed July 28, 2011.

8. Government of Canada. Canada's Fourth National Report on Climate Change: Actions to Meet Commitments under the United Nations Framework Convention on Climate Change. Ottawa: Government of Canada; 2006. Available from: http://unfccc.int/resource/docs/natc/ cannc4.pdf. Accessed August 9, 2011.

9. Corvalan C, Hales S, McMichael A, et al. Ecosystems and Human Well-being: Health Synthesis. Geneva: World Health Organization; 2005. Available from: http://www.who.int/globalchange/ecosystems/ ecosys.pdf. Accessed August 10, 2011.

10. Ebi KL, Balbus J, Kinney PL, et al. Effects of global change on human health. In: Gamble JL, Ebi KL, Sussman TJ, Wilbanks, editors. Analyses of the Effects of Global Change on Human Health and Welfare and Human Systems. A Report by the US Climate Change Science Program and the Subcommittee on Global Change Research. Washington DC: US Environmental Protection Agency; 2008:2-1-2-72. Available from: http://www.climatescience.gov/Library/sap/sap4-6/final-report/ sap4-6-final-all.pdf. Accessed August 10, 2011. 
11. Interagency Working Group on Climate Change and Health. A Human Health Perspective on Climate Change: A Report Outlining the Research Needs on the Human Health Effects on Climate Change. Research Triangle Park, NC: Environmental Health perspectives/National Institute of Environmental Health Sciences. Available from: http://www.niehs. nih.gov/climatereport. Accessed June 17, 2011.

12. McMichael AJ, Woodruff RE, Hales S. Climate change and human health: present and future risks. Lancet. 2006;367:859-869.

13. Patz JA, Campbell-Lendrum D, Holloway T, Foley JA. Impact of regional climate change on human health. Nature. 2005;438:3103-3117.

14. Epstein PR. Climate change and human health. $N$ Engl J Med. 2005;353:1433-1434.

15. Frumkin H, McMichael AJ, Hess JJ. Climate change and the health of the public [theme issue]. Am J Prev Med. 2008;35(5):401-402.

16. St Louis ME, Hess JJ. Climate change: impacts on and implications for global health. Am J Prev Med. 2008;35(5):527-538.

17. McMichael AJ, Campbell-Lendrum DH, Corvalan CF, et al. Climate Change and Human Health: Risks and Responses. Geneva: World Health Organization; 2003.

18. McMichael AJ, Friel S, Nyong A, Corvalan C. Global environment change and health: impacts, inequalities, and the health sector. $\mathrm{Br}$ Med J. 2008;336:191-194.

19. World Health Organization. Health and Climate Change: The "Now and How" - A Policy Action Guide. Copenhagen: World Health Organization; 2005.

20. Epstein PR, Mills E, editors. Climate Change Futures - Health, Ecological and Economic Dimensions. Cambridge, MA: The Center for Health and the Global Environment, Harvard Medical School; 2005.

21. Adger WN. Vulnerability. Glob Environ Change. 2006;16:268-281.

22. Huang $C$, Vaneckova $P$, Wang $X$, et al. Constraints and barriers to public health adaptation to climate change: a review of the literature. Brit Med J. 2011;400(11): 183-190.

23. Frumkin H, McMichael AJ. Climate change and public health: thinking, communicating, acting. Am J Prev Med. 2008;35:403-410.

24. Frumkin H, Hess J, Luber G, Malilay J, McGeehin M. Climate change: the public health response. Am J Public Health. 2008;98:435-445.

25. Keim ME. Building human resilience: the role of public health preparedness and response as an adaptation to climate change. Am J Prev Med. 2008;35:508-516.

26. Menne B, Ebi K. Climate Change and Adaptation Strategies for Human Health. Darmstadt: Steinkopff Verlag; 2005.

27. Griffiths J, Rao M, Adshead F, Thorpe A, editors. The Health Practitioner's Guide to Climate Change - Diagnosis and Cure. London: Earthscan; 2009.

28. Leonardi G. How to prepare for the health effects of climate change. In: Griffiths J, Rao M, Adshead F, Thorpe A, editors. The Health Practitioner's Guide to Climate Change - Diagnosis and Cure. London: Earthscan; 2009: 321-354.

29. Gill M. Why should doctors be interested in climate change? Br Med J. 2008;306:1506.

30. Menne B, Bertollini R. Health and climate change: a call for action. $\mathrm{Br}$ Med J. 2005;331:1283-1284.

31. Stern N. The Economics of Climate Change: The Stern Review. New York, NY: Cambridge University Press; 2006.

32. Ackerman F, Stanton EA, Hope C, Alberth S, Fisher J, Biewald B. The Cost of Climate Change: What We Will Pay if Global Warming Continues Unchecked. New York, NY: Natural Resources Defence Council; 2008. Available from: http://www.nrdc.org/globalwarming/cost.pdf. Accessed July 2, 2009.

33. Ouranos Consortium on Regional Climatology and Adaptation to Climate Change. Learning to Adapt to Climate Change. Montreal: Ouranos Consortium; 2010. Available from: http://www.ouranos.ca/ en/pdf/LearningAdapt2010.pdf. Accessed July 28, 2011.

34. Bourque A, Simonet G. Quebec. In: Lemmen DS, Warren FJ, Lacroix J, Bush E, editors. Impacts to Adaptation: Canada in a Changing Climate 2007. Ottawa: Government of Canada; 2008: 171-226. Available from: http:// adaptation.nrcan.gc.ca/assess/2007/index_e.php. Accessed July 28, 2011.
35. Bélanger D, Tairou FO, Bustinza R, Gosselin P. Proposition d'indicateurs aux fins de vigie et de surveillance des troubles de la santé lies aux vents violents [Suggested Indicators for the Surveillance of Possible Health Problems Related to Violent Winds]. Quebec: Direction de la santé environnementale et de la toxicologie, Institut national de santé publique du Québec; 2010. [French.]

36. Bélanger D, Gosselin P, Valois P, Abdous B. Vagues de froid au Québec méridional: adaptations actuelles et suggestions d'adaptations futures [Cold Waves in Southern Quebec: Current Adaptation Measures and Suggestions for Future Adaptation Strategies]. Quebec: Institut national de santé publique du Québec. Available from: http://www.inspq.qc.ca/ publications $/$ default.asp? $E=$ p \&Theme $=8$. Accessed September 20, 2008. [French.]

37. Bélanger D, Gosselin P. Changements climatiques au Québec méridional: perceptions de la population générale et suggestions d'adaptations futures [Climate Change in Southern Quebec: Perceptions of the General Population and Suggestions for Future Adaptation Strategies]. Quebec: Institut national de santé publique du Québec. Available from: http:// www.inspq.qc.ca/publications/default.asp?E $=\mathrm{p} \&$ Theme $=8$. Accessed September 20, 2008. [French.]

38. Bélanger D, Gosselin P, Poitras P. Changements climatiques au Québec méridional: perceptions des gestionnaires municipaux et de la santé publique [Climate Change in Southern Quebec: Perceptions of Municipal and Public Health Managers]. Quebec: Institut national de santé publique du Québec. Available from: http://www.inspq.qc.ca/publications/default. asp?E=p\&Theme=8. Accessed September 20, 2009. [French.]

39. Giguère M, Gosselin P. Eau et santé: Examen des initiatives actuelles d'adaptation aux changements climatiques au Québec [Water and Health: Study of Current Initiatives for Adaptation to Climate Change in Quebec]. Quebec: Institut national de santé publique. Available from: http://www.inspq.qc.ca/publications/default.asp?E=p\&Theme=8. Accessed September 20, 2009. [French.]

40. Giguère M, Gosselin P. Événements climatiques extrêmes et santé: Examen des initiatives actuelles d'adaptation aux changements climatiques au Québec. [Extreme Weather Events and Health: Study of Current Initiatives for Adaptation to Climate Change in Quebec]. Quebec: Institut national de santé publique. Available from: http://www.inspq. qc.ca/publications/default.asp?E=p\&Theme $=8$. Accessed September 20, 2009. [French.]

41. Giguère M, Gosselin P. Maladies zoonotiques et à transmission vectorielle: Examen des initiatives actuelles d'adaptation aux changements climatiques au Québec [Zoonotic and Vector-borne Diseases: Study of Current Initiatives for Adaptation to Climate Change in Quebec]. Quebec: Institut national de santé publique. Available from: http:// www.inspq.qc.ca/publications $/$ default.asp? $E=p \& T h e m e=8$. Accessed September 20, 2009. [French.]

42. Giguère M, Gosselin P. Vagues de chaleur, effet d'îlot thermique urbain et santé: Examen des initiatives actuelles d'adaptation aux changements climatiques au Québec [Heat Waves, Urban Heat Islands and Health: Study of Current Initiatives for Adaptation Change in Quebec. Quebec: Institut national de santé publique]. Available from: http://www.inspq. qc.ca/publications $/$ default.asp?E $=$ p\&Theme $=8$. Accessed September 20, 2009. [French.]

43. Bernier E, Gosselin P, Badard T, Bédard Y. Easier surveillance of climate-related health vulnerabilities through a Web-based spatial OLAP application. Int J of Health Geographics. 2009;8:18.

44. Smith K. Symposium introduction. Mitigating, adapting, and suffering: how much of each? Annu Rev Public Health. 2008;19:1125.

45. Kein RTJ, Schipper EL, Dessai S. Integrating mitigation and adaptation into climate and development strategies: three research questions. Environ Sci and Pol. 2005;8:579-588.

46. Costello A, Abbas M, Allen A, et al. Managing the health effects of climate change: Lancet and University College London Institute for Global Health Commission. Lancet. 2009;373:1693-1733.

47. Ebi KL, Smith J, Burton I, Scheraga J. Some lessons learned from public health on the process of adaptation. Mitigation and Adaptation Strategies for Global Change. 2006;11:607-620. 
48. Grambsch A, Menne B. Adaptation and adaptive capacity in the public health context. In: McMichael AJ, Campbell-Lendrum DH, Corvalan CF, et al. Climate Change and Human Health: Risks and Response. Geneva: World Health Organization; 2003:1-17.

49. Ebi KL. Public health responses to the risks of climate variability and change in the United States. J Occup Environ Med. 2009;5:1.

50. Ebi KL, Smith JB, Burton I. Integration of Public Health with Adaptation to Climate Change: Lessons Learned and New Directions. London: Taylor and Francis; 2005.

51. Griffiths J, Stewart L. Sustaining a Healthy Future: Taking Action on Climate Change. 2nd ed. London: Faculty of Public Health; 2009.

52. Menne B, Bertollini R. Health and climate change: a call for action. $\mathrm{Br}$ Med J. 2005;331:1283-1284.

53. Smit B, Klein RJT, Street R. The science of adaptation: a framework for assessment. Mitigation Adaptation Strategies Global Change. 1999;4:1992-1913.

54. Kelly PM, Adger WN. Theory and practice in assessing vulnerability to climate change and facilitating adaptation. Clim Change. 2000;47:325-352.

55. Brooks N, Adger WN, Kelly PM. The determinants of vulnerability and adaptive capacity at the national level and the implications for adaptation. Glob Environ Change. 2006;15:151-163.

56. Kovats S, Ebi KL, Menne B. Methods of Assessing Human Health Vulnerability and Public Health Adaptation to Climate Change. Geneva World Health Organization, Health Canada, World Meteorological Organization and United Nations Environment Programme. Available from: http://www.euro.who.int/InformationSources/Publications/ Catalogue/20041118_. Accessed September 23, 2009.

57. Füssel HM, Klein RJT. Climate change vulnerability assessments: an evolution of conceptual thinking. Clim Change. 2006;75: 301-329.

58. Séguin J, Clarke KL. Introduction. In: Séguin J, Berry P. Human Health in a Changing Climate: A Canadian Assessment of Vulnerabilities; Synthesis Report. Ottawa: Health Canada; 2008: 1-26. Available from: http://www.ptaff.ca/blogue/wp-content/uploads/human_health_in_a_ changing_climate.pdf. Accessed July 28, 2011.

59. Cohen SG. Complex collaborations in the new global economy. Organ Dyn. 2003;31:117-1133.

60. Haythornthwaite C. Learning and knowledge networks in interdisciplinary collaborations. Am Society Inform Sci Techno. 2006;57:1079-1092.

61. Lapaige V. Adaptive transfrontier ecoLearning for climate change-oriented eHealth and climate-sensitive psychopathology. In: EDULEARN11 Proceedings $C D$. Proceedings of the 3rd International Conference on Education and New Learning Technologies, Barcelona, Spain, July 4-6, 2011. Valencia: International Association of Technology, Education and Development; 2001: 2031-2035. Available from: http://www.iated.org/ edulearn11/publications. Accessed August 29, 2011.

62. Marrec A, Rinfret N. Le technoleader de résonance. Mythe ou réalité? [The Technoleader in Resonance. Myth or Reality?]. Quebec: Presses de l'Université du Québec; 2011. [French.]

63. Hirsh Hadorn G, Hoffmann-Riem H, Biber-Klemm S, et al. Handbook of Transdisciplinary Research. Bern: Springer Sciences and Business Media BV; 2008.

64. Nicolescu B, editor. Transdisciplinarity. Theory and Practice. Cresskill, NJ: Hampton Press; 2008.

65. Stokols D. Towards a science of transdisciplinary action research. Am J Com Psychol. 2008;38:63-77.

66. Bammer G. Integration and implementation science: building a new specialization. Ecol Soc. 2005;10:2.

67. Lee CK, Foo S. Narratives in healthcare. In: Bali RK, Dwivedi AN, editors. Healthcare Knowledge Management. Issues, Advances, and Successes. New York, DC: Springer; 2007: 130-141.

68. Greenhalgh T, Hurwitz B. Why study narrative? In: Greenhalgh T, Hurwitz B, editors. Narrative Based Medicine: Dialogue and Discourse in Clinical Practice. London: BMJ Books; 1998.

69. Linde C. Narrative and social tacit knowledge. Journal of Knowledge Management. 2001;5:160-170.
70. Fisher WR. Narration as a human communication paradigm: the case of public moral argument. Commun Monogr. 1984:51:1-22.

71. Cohen D, Prusak L. In Good Company: How Social Capital Makes Organizations Work. Boston, MA: Harvard Business School; 2001.

72. Sakalys JA. Restoring the patient's voice: the therapeutics of illness narratives. J Holistic Nurs. 2003;21:228-241.

73. Greenhalgh T, Hurwitz B, editors. Narrative Based Medicine: Dialogue and Discourse in Clinical Practice. London: BMJ Books; 1998.

74. Charon R. Narrative medicine: a model for empathy, reflection, profession and trust. JAm Med Assoc. 2001;286:1897-1902.

75. Chee YC. Heroes and heroines of the war on SARS. Singapore Med J. 2003;44:221-228.

76. Frank AW. The standpoint of the storyteller. Qual Health Res. 2000;10:354-365.

77. World Health Organization Europe. Declaration of the Third Ministerial Conference on Environment and Health. London, June 16-18 1999. Available from: http://www.euro.who.int/Document/E69046.pdf. Accessed March 5, 2009.

78. Kelly MP. Mapping the life-world: a future research priority for public health. In: Killoran A, Swann C, Kelly MP, editors. Public Health Evidence. Tackling Health Inequalities. Oxford and New York, NY: Oxford University Press; 2006: 553-573.

79. McMichael AJ. Planetary Overload: Global Environmental Change and the Health of Human Species. New York, NY: Cambridge University Press; 1993.

80. Bergeron L, Lacroix J, Vigeant G. L'étude pancanadienne sur le changement climatique - Tome V, chapitre Québec [Canada-wide Study on Climate Change - Volume V, Chapter Quebec]. Ottawa: Environnement Canada; 1997. [French.]

81. Kattsov VM, Kallen E, Cattle H, et al. Future climate change: modeling and scenarios for the Arctic. In: Weller G, Bush E, Callaghan TV, et al, editors. Arctic Climate Impact Assessment (ACIA). London: Cambridge University Press; 2005: 100-150.

82. Weller G, Bush E, Callaghan TV, et al. Summary and Synthesis of the ACIA, Climate Impact Assessment (ACIA). Cambridge, UK: Cambridge University Press; 2005.

83. Furgal C, Martin D, Gosselin P. Climate change and health in Nunavik and Labrador: Lessons from Inuit knowledge. In: Krupnik I, Jolly D, editors. The Earth is Faster Now: Indigenous Observations of Arctic Environmental Change. Washington, DC: Arctic Research Consortium of the United States, Arctic Studies Centre, Smithsonian Institution; 2002:266-300.

84. ArcticNet. Network of Centres of Excellence of Canada on the Arctic and the Climate. Rationale. Quebec: ArcticNet; 2011. Available from: http://www. arcticnet.ulaval.ca/aboutus/rationale.php. Accessed August 10, 2011.

85. ArcticNet. Impacts of Environmental Change in the Canadian Coastal Arctic: A Compendium of Research Conducted during ArcticNet Phase I (2004-2008). Quebec: ArcticNet; 2011.

86. Dewailly E, Ayotte P, Pereg D, Déry S, Dallaire R, Fontaine J, Côté S. Qanuippitaa? = How Are We? Exposure to Environmental Contaminants in Nunavik: Metals Kuujjuaq, QC. Montreal: Régie régionale de la santé et des services sociaux Nunavik, Institut national de santé publique du Quebec; 2007.

87. Furgal C, Gosselin P, Vézeau N. Climate, health and the changing Canadian North. In: Grover VI, editor. Global Warming and Climate Change. Ten Years after Kyoto and Still Counting. Hamilton, Canada: United Nations University, International Network on Water, Environmental and Health; 2008:761-799.

88. Owens S, Gosselin P, Furgal C, Proulx JF, Château-Degat L. Nunavik's Public Health Surveillance in Response to a Changing Climate: A Baseline Study. Quebec: Centre de recherche du CHUQ; 2006.

89. Lavoie E, Levesque B, Proulx JF, et al. Evaluation of the efficacy of the toxoplasma gondii screening program among pregnant women in Nunavik, 1994-2003. Can J Public Health. 2008;99: 397-400.

90. Martin D, Bélanger D, Gosselin P, Brazeau J, Furgal C, Déry S. Drinking water and potential threats to human health in Nunavik: adaptation strategies under climate change conditions. Arctic. 2007;60:195-202. 
91. Institut national de santé publique du Québec. Portrait de santé $d u$ Québec et de ses régions 2006. Les analyses (section 1.4) [State of Public Health in Quebec and its Regions in 2006. The Analyses (Section 1.4)]. Quebec: Institut national de santé publique du Québec; 2006. Available from: http://www.inspq.qc.ca/pdf/publications/ portrait_de_sante.asp?E=p. Accessed December 4, 2006. [French.]

92. Ouranos and Environnement Canada. Centre de ressources en impacts et adaptation au climat et à ses changements [Resource Centre for Impacts of and Adaptation to Climate Change]. 2009. Available from: http://www.criacc.qc.ca/climat/suivi/saguenay/saguenay_f.html. Accessed March 4, 2009. [French.]

93. Environment Canada. Atmospheric Hazards. Ontario Region. Available from: http://ontario.hazards.ca/historical/Ice_Ontario-f.html. Accessed July 28, 2011.

94. Library and Archives Canada. Ice Storm 1998 - January 5-10, 1998. In: SOS! Canadian Disasters [website on the Internet]. Ottawa: Library and Archives Canada; 2006 [updated February 14]. Available from: http://www.collectionscanada.gc.ca/sos/002028-5100-e.html. Accessed September 6, 2011.

95. Bouden M, Moulin B, Gosselin P. The geosimulation of West Nile virus propagation: a multi-agent and climate sensitive tool for risk management in public health. Int J Health Geographics. 2008;7:35. Available from: http://www.ij-healthgeographics.com/content/7/1/35. Accessed July 25, 2011.

96. Doyon B, Bélanger D, Gosselin P. The potential impact of climate change on annual and seasonal mortality for three cities in Québec, Canada. Int J Health Geographics. 2008;7:23. Available from: http://www.ijhealth geographics.com/content/7/1/23. Accessed July 25, 2011.

97. Doyon B, Bélanger D, Gosselin P. Effets du climat sur la mortalité au Québec méridional de 1981 à 1999 et simulations pour des scénarios climatiques futurs [Effects of Climate Change on Mortality in Southern Quebec from 1981 to 1999 and Simulations for Future Climate Scenarios]. Quebec: Institut national de santé publique du Québec; 2006. Available from: http://www.inspq.qc.ca/publications/default. asp?E $=$ p\&Theme $=8$. Accessed February, 2007. [French.]

98. El Adlouni S, Beaulieu C, Ouarda T, Gosselin P, Saint-Hilaire A. Effects of climate on West Nile Virus transmission risk used for public health decision-making in Québec. Int J Health Geographics. 2007;6:40. Available from: http://www.ij-healthgeographics.com/content/6/1/40/ abstract. Accessed July 25, 2011.

99. Garneau M, et al. Hausse des concentrations polliniques causée par le changement climatique et ses conséquences potentielles sur les maladies respiratoires des populations vulnérables en milieu urbain [Climate change-related increase of pollens concentrations and its possible consequences on vulnerable populations' respiratory diseases in urban environment]. UQAM and Ouranos. Projet FACC; 2005. Available from: http://www.ouranos.ca/media/publication/34_Rapport_ Garneau_sante_2006.pdf. Accessed August 29, 2011. [French.]
100. Giguère M. Les impacts des vagues de chaleur et de l'effet d'îlot thermique urbain sur la santé : examen des initiatives d'adaptation actuelles au Québec [Heat Waves and Heat Urban Island Impacts on Human Health: Study of Current Initiatives for Adaptation to Climate Change in Quebec]. Paper presented at the University Centre for Environmental Training. Sherbrooke: University of Sherbrooke; 2005. [French.]

101. Ministry of Sustainable Development, Environment and Parks. Québec and Climate Change: A Challenge for the Future. 2006-2012 Action Plan. Quebec: Ministry of Sustainable Development, Environment and Parks; 2008. Available from: http://www.mddep.gouv.qc.ca/changements/plan_action/index.htm. Accessed July 25, 2011.

102. Toutant S, Gosselin P, Bélanger D, Bustinza R, Rivest S. An open source web application for the surveillance and prevention of the impacts on public health of extreme meteorological events: the SUPREME system. Int J Health Geographics. 2011;9:39.

103. Government of Québec. Règlement relatif à la redevance annuelle au Fonds vert. Lois sur la Régie de l'énergie. Décret 1049-2007, 28 novembre 2007 [The Annual Fee to the Green Fund Regulations. The Board of the Energy Legislation. Order 1049-2007, November 28, 2007]. Quebec: Gazette officielle du Québec. Available from: http:// www.regie-energie.qc.ca/regie/Decrets/Decret_1049-2007_nov07.pdf. Accessed July 26, 2011. French.

104. Lapaige V. eEcohealth: Adaptive transfrontier ecoLearning for climate change-oriented eHealth and climate-sensitive psychopathology. Edulearn. 2011;11:2031-2035.

105. Lapaige V. e-Écoapprentissages, santé mentale et climat: une chaire de recherche INSPQ sur l'application transfrontières des connaissances [eEcoLearning, mental health and climate change: a QNPHI (Quebec National Public Health Institute) research chair on transfrontier education and knowledge translation]. Bulletin d'information en Santé Environnementale [serial on the Internet]. $9 \mathrm{Feb} 2011 ; 22(1): 8$. Theme issue on knowledge translation. Available from: http://www.inspq.qc.ca/ bise/post/2011/02/09/9-c2ab-E-ECOAPPRENTISSAGES-SANTEMENTALE-ET-CLIMAT-c2bb-UNE-CHAIRE-DE-RECHERCHEINSPQ-SUR-Le28099 APPLICATION-TRANSFRONTIERESDES-CONNAISSANCES.aspx. Accessed July 26, 2008. [French.]

106. Lapaige V. The emergence of weather-related disaster public health and mental health discipline: Web 2.0 and Web 3.0 continuing education is required. International Conference of Education, Research and Innovation, Madrid, Spain (November 14-16, 2011). In: ICERI2011 Abstracts CD, ICERI2011 Proceedings CD. Icera 2011. In press.

107. Lapaige V. Le Québec face au défi croisé de l'application des savoirs en santé climatique [Quebec facing the challenge of knowledge translation and education in climate change-related health]. Glob Health Prom. 2010;17(4):72-88. Available from: http://ped.sagepub.com/ content/17/4/72.full.pdf+html. Accessed June 17, 2011. [French.]

\section{Publish your work in this journal}

The Journal of Multidisciplinary Healthcare is an international, peerreviewed open-access journal that aims to represent and publish research in healthcare areas delivered by practitioners of different disciplines. This includes studies and reviews conducted by multidisciplinary teams as well as research which evaluates the results or conduct of such teams or

\section{Dovepress}

healthcare processes in general. The journal covers a wide range of areas and welcomes submission from practitioners at all levels, from all over the world. The manuscript management system is completely online and includes a very quick and fair peer-review system. Visit http://www.dovepress.com/testimonials.php to read real quotes from published authors. 